\title{
Characterization and genetic variability of barley accessions (Hordeum vulgare L.) irrigated in the savannas based on malting quality traits
}

\author{
Renato Fernando Amabile, ${ }^{1 *}$ Fábio Gelape Faleiro, ${ }^{1}$ Flávio Capettini, ${ }^{2}$ \\ Ricardo Meneses Sayd, ${ }^{3}$ José Ricardo Peixoto ${ }^{3}$ and Rosana Ferrari Guercia ${ }^{4}$
}

\begin{abstract}
The purpose of the study was to characterize and quantify the genetic variability of $\mathbf{3 0}$ elite barley malt accessions irrigated in the savannas, using traits related to the industrial quality to verify if they could be used in improvement programmes in the selection of better malt quality genotypes. The following analytical determinations were carried out: total protein content (\%), extract yield M.F. i.a. (\%), Hartong index VZ $\left(45^{\circ} \mathrm{C}\right)$, viscosity $8.6^{\circ} \mathrm{P}$ ( $\mathrm{mPa}$ s), boiled wort colour (EBC), soluble nitrogen content $(\mathrm{mg} / 100 \mathrm{~g})$, Kolbach index (\%), friability (\%) and $\beta$-glucan. The descriptive analysis of data was performed and the coefficients of genetic dissimilarity were estimated for each pair. The relative contribution of each trait of genetic diversity was measured and also the correlations among them. According to the genetic dissimilarity matrix, a cluster analysis and scatter chart were constructed. Through cluster analysis, two major similarity groups were observed. The soluble nitrogen was the variable that contributed the most for the genetic variability $(86.6 \%)$, followed by $\beta$-glucan $(12.5 \%)$. The results indicate that the barley grown in the savanna is ready to be included in the national malt process and that there is a genetic variability among the barley genotypes evaluated for the malting quality traits. It can be concluded that the barley can be used in the Brazilian irrigated barley improvement programme. The qualitative traits that contribute the most to the genetic diversity are soluble nitrogen and $\beta$-glucan and the less variable ones are protein content and malt viscosity. Copyright $\odot 2014$ The Institute of Brewing \& Distilling
\end{abstract}

Keywords: malt; genetic diversity; genetic resources; irrigated barley and malt quality

\section{Introduction}

Barley was one of the first domesticated crops and has been used as a regular source of food, being part of several links in the food industry, mainly in the malting industry (1). Barley grain is mainly used in human food and in industry (2). In Brazil, the barley used for malt dictates the culture and grain profile, and comprises about $85 \%$ of all of the harvested crop. The remaining amount is used as human food, animal feed and as seeds (3).

Barley is an alternative crop for the irrigated system in the savanna, showing good adaptability to the edaphoclimatic conditions of this biome, low incidence of disease and high yield potential. From an industrial point of view, barley grown in the savanna shows clean seeds, which might be used as malt immediately after being harvested, avoiding long stocking periods to complete the maturation of grains (4).

Cerrado (savanna) is the second largest biome in Brazil after the Amazon. It is the largest savanna in the world with around 2.0 million $\mathrm{km}^{2}$ (5). It is characterized by a bimodal weather system, that is, a very well defined rainy season from October to April, with precipitation ranging from 1200 to $1800 \mathrm{~mm}$, and a dry season that begins in May and finishes in September (6). Average air temperature ranges from 22 to $27^{\circ} \mathrm{C}$. These temperatures are low because of the latitude and also the influence of air mass coming from the southern part of Brazil (6).
Latosols are the most common type of soil (46\%), being also most frequently found in areas that use irrigation systems. This type of soil shows a high degree of weathering, low cationic exchange capacity, high levels of acid, high phosphorus adsorption capacity and, consequently, low natural fertility, with an organic matter content between 2 to 3\% (7). In terms of agriculture, the barley grown in the savanna under an irrigation system has been shown to be an adapted crop, with a high yield potential, a commercial yield above $5.0 \mathrm{t} / \mathrm{ha}$, and excellent commercial classification and grain quality (3).

* Correspondence to: Renato Fernando Amabile, Embrapa Cerrados, BrasíliaDF, Brazil, BR 020, Km 18, PO Box 08223, CEP 73010-970 Planaltina, DF, Brazil. E-mail: renato.amabile@embrapa.br

1 Embrapa Cerrados, Brasília DF, Brazil, BR 020, Km 18, PO Box 08223, CEP 73010-970 Planaltina, DF Brazil

2 Field Crop Development Centre, Alberta Agriculture and Rural Development, 503050 Street Lacombe, AB T4L 1W8, Canada

${ }^{3}$ College of Agriculture and Veterinary Medicine, University of Brasília, Campus Universitário Darcy Ribeiro, CEP 70910-900 Brasília, DF Brazil

${ }^{4}$ Malteria do Vale, Rua José Renato Cursino de Moura, 2001, CEP 12.051-150 Taubaté, SP Brazil 
In this context, it is important to study the divergence and genetic relationships regarding the industrial quality traits among the barley accessions. This is true because the characterization provides information on the germplasm collections (8), as well as the identification of better genotypes, which will be used in hybridizations as parents (9). Therefore, the genetic variability helps in consolidating the local productive systems and also in increasing the market price of new agricultural products.

Some authors report the existence of a narrow malting barley genetic base $(10,11)$; however other studies have shown that there is a wide variability of malting quality barley cultivars (12-14). Wright (15) stated that barley with industrial quality should be tested in order to use it in industry and in new potential areas favourable to barley culture, since the barley composition and characteristics have a strong influence on the processing properties and industrial products manufactured (16). Even after the successful introduction of barley in the irrigated savanna, little is known about the genetic variability existing in the germplasm banks regarding malting industry aspects, as well as the performance of these accessions in this environment.

In order to grow malting barley, breeding programmes should not only meet the demands of a higher yield but also obtain stable genotypes with appropriate malt quality traits as required by the malting industry. Therefore, genetic improvement is the first strategy to obtain superior barley genotypes adapted to new environments and industrial needs. However, as the traits related to the malt quality are affected by the environment (14), genotype characterization in the specific environments of Brazil, in our case in the savanna, is necessary to verify the association among these factors.

Therefore, malting quality traits should be measured, studied and used as selection criteria in the barley improvement programme to evaluate the use of accessions with the purpose of selecting superior malting quality genotypes and also to verify associations among the quality traits. In this context, the aim of this present study was to characterize and quantify the genetic variability of 30 elite accessions of the irrigated malting barley grown in the savanna, using traits that indicate the industrial quality, through micro-malting analysis.

\section{Materials and methods}

The experiments were carried out in the Quality Laboratory of Malteria do Vale, Taubaté - São Paulo. Samples used in the research were obtained from an experiment performed in 2010, at the Experimental Field of Embrapa Cerrados, Planaltina - Federal District, Brazil, located at $15^{\circ} 35^{\prime} 30^{\prime \prime} \mathrm{S}$ latitude, $47^{\circ} 42^{\prime} 30^{\prime \prime} \mathrm{E}$ longitude and $1007 \mathrm{~m}$ above the sea, in a typical distrophic Dark Red Latossol soil with clay texture, under conventional irrigation.

The weather data during the study included minimum, average and maximum air temperatures of $13.8,20.7$ and $27.9^{\circ} \mathrm{C}$, respectively; minimum, average and maximum air humidities of $29.9,53.5$ and $79.3 \%$; average air speed of $1.9 \mathrm{~m} / \mathrm{s}$; average solar radiation of $444.9 \mathrm{cal} / \mathrm{cm}^{2} /$ day; and, during the drought season, lack of rain.

The average results of the soil analysis $(10-20 \mathrm{~cm})$ according to EMBRAPA (17), indicated a lack of Al; $38.2 \mathrm{mmolc} / \mathrm{dm}^{3}$ of $\mathrm{Ca}$; $8.4 \mathrm{mmolc} / \mathrm{dm}^{3}$ of $\mathrm{Mg} ; 24.69 \mathrm{mg} / \mathrm{kg}$ of $\mathrm{P} ; 6.8 \mathrm{mmolc} / \mathrm{dm}^{3}$ of $\mathrm{K}$; $23.0 \mathrm{~g} / \mathrm{kg}$ of organic matter; a pH (water) of 6.07; coarse sand= $60 \mathrm{~g} / \mathrm{kg}$; fine sand $=380 \mathrm{~g} / \mathrm{kg}$; silt $=130 \mathrm{~g} / \mathrm{kg}$; and clay $=430 \mathrm{~g} / \mathrm{kg}$.
The experimental design chosen was a complete randomized block with four replicates. A plot with six lines $5 \mathrm{~m}$ long with a spacing of $20 \mathrm{~cm}$ was used with a useful area of $4.8 \mathrm{~m}^{2}$ for each spot and a density of 300 plants $/ \mathrm{m}^{2}$. The soil was prepared by adding soy culture debris, using 32 inch disc plows, followed by the use of a 20 inch levelling disc. The herbicide pendimethalin in a pre-emergency situation was used (dose of 3.0 L/ha) and no insecticide or fungicide was necessary since there was no incidence of pests or diseases. According to the results from the soil analysis, $16 \mathrm{~kg} / \mathrm{ha}$ of $\mathrm{N}, 120 \mathrm{~kg} / \mathrm{ha}$ of $\mathrm{P}_{2} \mathrm{O}_{5}$, $64 \mathrm{~kg} / \mathrm{ha}$ of $\mathrm{K}_{2} \mathrm{O}$ and $40 \mathrm{~kg} / \mathrm{ha}$ of $\mathrm{N}$ were used in the seeding when the fifth leaf was present and totally unfolded.

The seeds were mechanically harvested when the relative air humidity ranged from 13 to $15 \%$, and stored in paper bags. Until the day of analysis they were stored in a room at $25 \pm 1^{\circ} \mathrm{C}$ temperature with a relative humidity of $30 \%$.

Thirty malting barley accessions with different origins (Table 1), obtained from the elite (grain yield and lodging) collection of Embrapa Cerrados, were studied. During malting, the samples were immersed in water for $4 \mathrm{~h}$, dried for $8 \mathrm{~h}$ and again immersed in water for an additional $2 \mathrm{~h}$. After this process, the seeds were settled to germinate under standardized temperature conditions for 4 days, where the daily temperatures, from the first to fourth day were 22, 20, 18 and $16^{\circ} \mathrm{C}$, respectively. The samples were dried and heated for a period of $22 \mathrm{~h}$ in an air forced circulation greenhouse, following a drying curve in a cycle of $4 \mathrm{~h}$ at $55^{\circ} \mathrm{C}, 11 \mathrm{~h}$ at $65^{\circ} \mathrm{C}$ and $3 \mathrm{~h}$ at $80^{\circ} \mathrm{C}$. The roasting process was performed in a cycle of $2 \mathrm{~h}$ at $83^{\circ} \mathrm{C}$, a further $2 \mathrm{~h}$ at $85^{\circ} \mathrm{C}$ and then at a temperature of $25-30^{\circ} \mathrm{C}$ for about $3 \mathrm{~h}$. Maceration, germination, drying and roasting were performed using connected equipment, that is, Seeger Type A1-2008 no. 170/1 (maceration and germination) and no. 170/2 (drying and roasting). The degermination was performed on vibrating screens. Following this process, the malt grinding was performed using a standard mashing process (Kongressmainchverfahren), standardized by the European Brewery Convention (18), enabling the comparison of the results in different samples, as well as their potential.

The following analytical determinations were performed on the resulting mash: total protein content (\%), according to Kjeldahl method (19), extract yield M.F. i.a. (\%), Hartong index VZ $\left(45^{\circ} \mathrm{C}\right)$, viscosity $8.6^{\circ} \mathrm{P}(\mathrm{mPa})$, boiled wort colour $(\mathrm{EBC})$, soluble nitrogen content $(\mathrm{mg} / 100 \mathrm{~g})$, Kolbach index (\%), friability (\%) and $\beta$-glucan, according to the methodology of the European Brewery Convention (18).

For each accession, a data descriptive analysis (mean, standard deviation, maximum and minimum values, variance and standard deviation) was carried out. Based on the data average, the coefficient of genetic dissimilarity was also estimated using the standardized average Euclidian distance, according to Steel and Torrie (20). The relative contribution of each trait for the genetic diversity was also measured using the Singh method (21) and Genes programme (22). The phenotypic correlations among the traits were estimated based on the Pearson correlation coefficient with the Statistic Genes (22). The intervals given by Carvalho et al. (23) were used to classify the correlations.

Based on the genetic dissimilarity matrix, cluster grouping through a dendogram was performed, using as cluster criteria the UPGMA (unweighted pair-group method arithmetic average) (24). The graphic dispersion, based on multidimensional scales with the principal coordinate method and with the aid of Statistica (25), was carried out. 
Table 1. Barley accessions characterized in the study and respective information on their use, or non use, in improvement programmes in Brazil, presence of two or six rows and geographical origin

\begin{tabular}{|c|c|c|c|c|}
\hline Number & Accessions & Accession used in Brazil & Two- and six-row groups & Groups by origin \\
\hline 1 & PFC 2001090 & Yes & Two-row & Brazil \\
\hline 2 & CEV 96046 & Yes & Two-row & Brazil \\
\hline 3 & PFC 213660 & Yes & Two-row & Brazil \\
\hline 4 & PFC 2003122 & Yes & Two-row & Brazil \\
\hline 5 & Foster & Yes & Six-row & USA \\
\hline 6 & $\mathrm{C}-70$ & No & Two-row & USA \\
\hline 7 & Lacey & Yes & Six-row & USA \\
\hline 8 & M 14 & No & Two-row & USA \\
\hline 9 & Alliot & No & Two-row & UK \\
\hline 10 & PFC 2005123 & No & Two-row & Brazil \\
\hline 11 & CIMMYT 42 & No & Six-row & Mexico \\
\hline 12 & CIMMYT 48 & No & Six-row & Mexico \\
\hline 13 & CIMMYT 25 & No & Six-row & Mexico \\
\hline 14 & Danuta & Yes & Two-row & Germany \\
\hline 15 & BRS 195 & Yes & Two-row & Brazil \\
\hline 16 & BRS 180 & Yes & Six-row & USA \\
\hline 17 & Cellar & Yes & Two-row & UK \\
\hline 18 & CPAC 20020098 & Yes & Six-row & Mexico \\
\hline 19 & BRS Deméter & Yes & Two-row & Brazil \\
\hline 20 & Scarlett & Yes & Two-row & Germany \\
\hline 21 & PFC 2004345 & No & Two-row & Brazil \\
\hline 22 & BRS Sampa & Yes & Two-row & Brazil \\
\hline 23 & PFC 2004216 & No & Two-row & Brazil \\
\hline 24 & BRS Elis & Yes & Two-row & Brazil \\
\hline 25 & PFC 98252 & No & Six-row & Brazil \\
\hline 26 & Vicente Morales & No & Six-row & Mexico \\
\hline 27 & BRS Greta & Yes & Two-row & Brazil \\
\hline 28 & PFC 99324 & Yes & Six-row & Brazil \\
\hline 29 & PFC 2004033 & Yes & Two-row & Brazil \\
\hline 30 & PFC 214827-10 & No & Two-row & Brazil \\
\hline
\end{tabular}

A stop in the clustering algorithm (dendrogram cut) was performed based on the average genetic distance among the genotypes. The cophenetic correlation coefficient $(r)$ among the original genetic distances and those represented by the dendrogram between the genotype pairs, according to Sokal and Rohlf (26), was calculated to estimate the adjustment between the dissimilarity matrix and the generated dendrogram using software NTSYS pc 2.1 (27).

\section{Results and discussion}

The characterization of 30 elite barley accessions irrigated in the savanna based on 10 traits related to the malting quality shows the genetic variability of this material (Table 2). This variability, under the conditions of the savanna and based on the analytical determinations of laboratory malt, was also found in other accessions characterized by Bichoński and Śmiałowski (28), Amabile et al. (29), Evans et al. (30) and Verma and Sarkar (31). The barley malting quality is extremely complex and is controlled by several genes, being strongly influenced by the environment $(32,33)$, mainly by the high air temperatures and water deficit during the grain filling (34). In the savanna, Amabile et al. (29) reported that the environment strongly influenced the barley under irrigation systems. Additionally, Molina-Cano et al. (14) have concluded that the interaction genotype $\times$ environment results in an unpredictable variation in the quantitative traits of malting quality.

According to the descriptive analysis, differences among the genotypes, in at least one standard deviation regarding the traits for industrial quality, were found, except for total protein and viscosity, indicating the existence of a probable genotypic variability among the 30 barley accessions evaluated (Table 2).

As for the protein, the contents ranged from 11.6\% (BRS 195) to $14.7 \%$ (PFC 2001090), with an average value of $13.38 \%$ (Table 2). This result was higher than what was observed by Amabile et al. (29), who found an average index of $12.87 \%$ for 57 genotypes tested in three different environments in the savanna. Amabile et al. (35-38) observed variability in the protein content of BRS 195 in the irrigated savanna for the PFC 2001090 genotype (10.9-13\%). This variability is considered to be one of the biggest problems with the barley grown in the Brazilian savanna (39).

The instability shown in the protein content indicated by Eagles et al. (40) is triggered by the amount of applied nitrogen, as well as water stress and other environmental factors imposed on the genotype $(14,34,41)$, as well as the response of each genotype to these influences. The result is large oscillations in the grain protein content, going from very low numbers (around $7-8 \%)$ up to extreme numbers $(>12 \%)$ - where the maximum level was established as $12 \%$ by Brasil (42). However, this content 


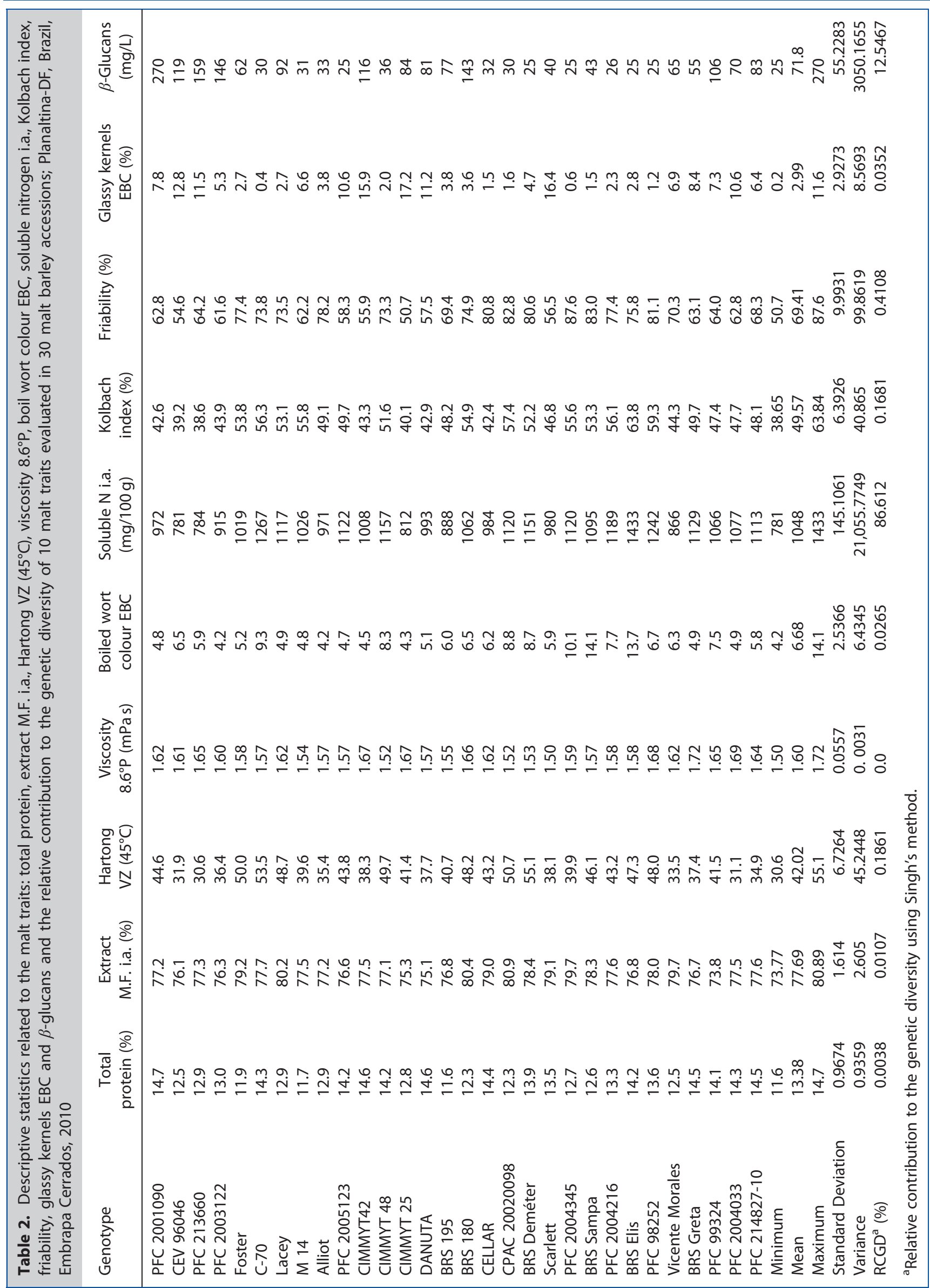


can be up to $12.5 \%(32,43)$. Table 2 illustrates that, even among the elite genotypes, only seven showed contents below $12.5 \%$, evidencing an interaction between the genotype and environment regarding this variable, as did the data reported by Molina-Cano et al. (14). In addition to the genetic effect on protein content in the grains, the high temperatures and low relative humidity during the grain filling period in the savannas probably resulted in an increased protein content, corroborating the theory described by Chapman and Carter (44), who stated that, in dry and hot environments, barley grains showed high protein content, and by Passarella et al. (34), who observed that high temperatures during the grain filling result in smaller grains and an increase in protein. However, it is emphasized that high concentrations of protein might be useful when those found in the Brazilian market are low, becoming a protein bank to be used for blending.

In order to identify and classify the different types of malt, a number of traits such as viscosity, Kolbach index, $\beta$-glucan, friability and extract, should be evaluated (45). When analysing the extract (Table 2), the extract genotypes ranged from 73.77 to $80.89 \%$, with an average of $77.69 \%$, being higher than the Brazilian standard (46) for roasted malt (65\%). However, when compared with the same legislation for the Pilsen malt, only CIMMYT 25, CIMMYT 42, CIMMYT 48 and PFC 99324 genotypes did not meet (Table 2) the specifications for six-rowed genotypes (78\%). These data highlight the potential for growing six-row barley under irrigation in the savanna and also the possibility of genotype hybridization using an extract that meets the malting industry needs in crossing. Only Scarlett (79.1\%) and Cellar (79.0\%) cultivars and PFC 2004345 (79.7\%) genotype showed an extract index higher than the limit value provided (46) for two-row barley in relation to Pilsen malt. According to Brasil (46), the registered BRS Deméter, DRS 195 and BRS Sampa cultivars recommended for the irrigated savanna do not show appropriate values (Table 2). Amabile et al. (47) obtained an extract index for BRS Deméter cultivar, with annual variation, but $>79 \%$. The same yearly variation was identified by Silva et al. (48) for BRS 180 cultivar. These results show that even genetic material already introduced as a malting barley might not maintain the index that it had when first introduced, owing to the influences of the environmental conditions $(31,49)$.

The Hartong index $\left(\mathrm{VZ} 45^{\circ} \mathrm{C}\right.$ ) ranged from 30.6 to 55.1 (Table 2). Nine accessions showed numbers below the value recommended (38) by Brasil (46), both for two- and six-rowed grains, evidencing a low enzyme activity. A high Hartong index is thought to reflect the degree of malt modification, such that a higher value corresponds to better modification (50). Therefore, the high values found indicate a good malt modification obtained from genotypes grown in the irrigated savanna. In general, genotypes present excellent performance, although, according to Brasil (46), a value $>50 \%$ does not indicate a high malt quality, observed in accession C 70 (53.5\%) and BRS Deméter $(55.1 \%)$ cultivar. The high value for BRS Deméter is in accordance with the data observed by Amabile et al. (47). The BRS 180 cultivar also showed a value of 48.2 , higher than those found by Silva et al. (48), which ranged according to the micromalting performed. According to Ogushi et al. (51), high values might be explained by the modification stage of the malt and malting process used or might be partially elucidated by the higher level of starch degradation along with the higher thermostability of the $\beta$-amylase.
The data variability regarding the viscosity was $1.50-1.72$ (Table 2), being considered high according to Brasil (46), since the maximum value is 1.60 . A high viscosity results in a longer beer clarification process and a difficult filtration. Following the same tendency of the extract, BRS 180 and BRS Deméter cultivars showed higher viscosity values than those verified by Silva et al. (48) and Amabile et al. (47). These high values might be also related to the high protein content in the grains, according to statements made by Mather et al. (33). Ogushi et al. (52) stated that viscosity is more strongly influenced by genetic components than by environmental effects, which might explain the results obtained in the present research.

The colour after boiling is directly related to the final colour of the product. Currently, the tendency is to obtain low levels of colour to address the demands of the malting industry (53). The colour range found in the present study was 4.2-14.1 (Table 2). As for the Pilsen malt, the maximum allowed is 6.0 (46). However, breweries accept a colour after boiling ranging from 6.0 to 7.5 (54). It could be observed that 16 accessions met the specification by Brasil (46), while 22 genotypes followed the recommendations from Reinold (54) - among them BRS 180 (6.5) and BRS Deméter (8.7) cultivars (Table 2). This kind of performance shows that the genetic constitution of the samples tested is promising in terms of colour for the Pilsen malt.

The soluble nitrogen and Kolbach indexes are related to the malt protein solubilization (18). During mashing, the soluble part of the nitrogen is separated. The higher the proteolytic enzyme activity during malting, the higher the soluble nitrogen. Table 2 shows that the soluble nitrogen ranged from 781 (CEV 96046) to $1433 \mathrm{mg} / 100 \mathrm{~g}$ (BRS Elis). Brasil (46) expresses values from 510 to $960 \mathrm{mg} / 100 \mathrm{~g}$, where an approximate value of 690 is considered the ideal. Only six genotypes showed values within the expected for the Pilsen malt: CEV 96046, PFC 213660, PFC 2003122, Vicente Morales, CIMMYT 25 and BRS 195.

On the other hand, the Kolbach index is an important tool to provide information on the protein modification and reflects the relationship between the soluble and total nitrogen (18). The index for the accessions ranged from $38.65 \%$ (PFC 213660) to $63.84 \%$ (BRS Elis) (Table 2). All genotypes had an index higher than $38 \%$, which is the borderline content recommended by Brasil (46). Considering the superior limit proposed by Fox (55), which is $49.9 \%, 17$ genotypes met this requirement. BRS 180 as well as BRS Deméter showed higher values than those reported by Silva et al. (48) and Amabile et al. (47). However, Amabile et al. (29) found similar or lower values for these cultivars and also for Foster, Lacey, PFC 213660 and BRS 195, among others, in agreement with the results from Kaczmarek et al. (56) and Sarkar et al. (57). These authors also observed a genetic $\times$ environment interaction to explain the index variability.

The friability value provides a physical measure of barley modification, mainly regarding filtration and uniformity. The values for this trait ranged from 50.7 to $87.6 \%$, where $50 \%$ of the genotypes (Table 2) showed higher values than the minimum provided by Fox (55), which is $70 \%$. These results, when compared with the ones found by Amabile et al. (29), show the environmental influence on this trait, in agreement to what was reported by Ogushi et al. (52).

In relation to the trait 'glassy', the values ranged from 0.2 (C 70) to $11.6 \%$ (Scarlett). However, about $80 \%$ of the evaluated genotypes were below the maximum limit (5\%) recommended by Brasil (46). 
Even with the high standard deviation observed for the $\beta$-glucan trait (Table 2), only PFC 2001090 genotype showed a content of $270 \mathrm{mg} / \mathrm{L}$, which was higher than the content ( $200 \mathrm{mg} / \mathrm{L}$ ) described by the Australian Committee Malting and Brewing Industry Barley Technical Committee (55). The average $(71.8 \mathrm{mg} / \mathrm{L})$ was lower than that observed by Eagles et al. (40), who performed a study of two Australian collections and found values equal to 509 and $374 \mathrm{mg} / \mathrm{L}$, with the accessions showing high values for the malting barley $(1.556 \mathrm{mg} / \mathrm{L})$. It is important to highlight that malting barley shows a low content of $\beta$-glucan $(58,59)$, since it has the property of forming colloids, which can negatively affect the brewing process, more specifically filtration. On the other hand, it is known that $\beta$-glucans are strongly influenced by genetic factors $(14,52)$ and other research has considered the environmental effects over this variable $(2,60)$. Along with the information and results found, it is concluded that the genetic constitutions that were evaluated might and should be used as genitors in the Brazilian barley improvement programme. These results also indicate that the environment tested contributed to a good performance of genotypes for this trait.

Malt quality is a result of multiple interactions among the quality variables and it is relatively difficult to choose one quality trait as a tool to select a genotype. The index of traits used to measure malt quality has been questioned (61), indicating a limitation to predicting the performance of genetic material. Therefore, when evaluating the information on the quality of genotypes tested, it was observed that CPAC 20020098, PFC 98252 and BRS Deméter, PFC 2004345 and BRS Sampa (although it had a high colour), Foster, Scarlett, Lacey and PFC 2004216 (low friability) genotypes and Cellar cultivar (high protein) all expressed a good association and could be selected as malting materials.

Another difficulty found in the selection of malting genotypes is the correlation among the quality traits. Table 3 illustrates the coefficient of phenotypic correlation among the traits analysed in the present research.

There was a wide variability in the degree and type of association among the traits analysed - not all of them showed a dependency relationship. A strong and highly significant correlation was found between the Kolbach index and N (0.8534), showing a high degree of dependency between these traits, in contrast $(-0.406)$ to what was found by Ogushi et al. (52). A strong negative and highly significant correlation was observed between the friability and glassy trait $(-0.7947)$. We also observed an average, but significant and positive, association among Hartong and Kolbach; Hartong and N; Kolbach and friability; and extract and friability. The latter was also found by Fox (45). The result between Hartong and N was expected since Hartong measures the enzyme activity and malt protein solubilization, being directly related to the soluble nitrogen. Since the Kolbach index is a value that has a significant meaning in the evaluation of the malt protein solubilization, it is particularly related to Hartong.

Similar to Molina-Cano et al. (14) and Wang and Zhang (62), a negative and highly significant correlation between the $\beta$-glucans and the Kolbach index was observed. The same was true for the dependency relationship between $\beta$-glucan and nitrogen, corroborating the data from Swanston (63) and Savin et al. (64). These authors proposed that low values of $\beta$-glucan are related to high nitrogen levels and that a dense protein might limit the $\beta$-glucanase activity in the endosperm cell wall, favouring this negative correlation. Friability and $\beta$-glucan

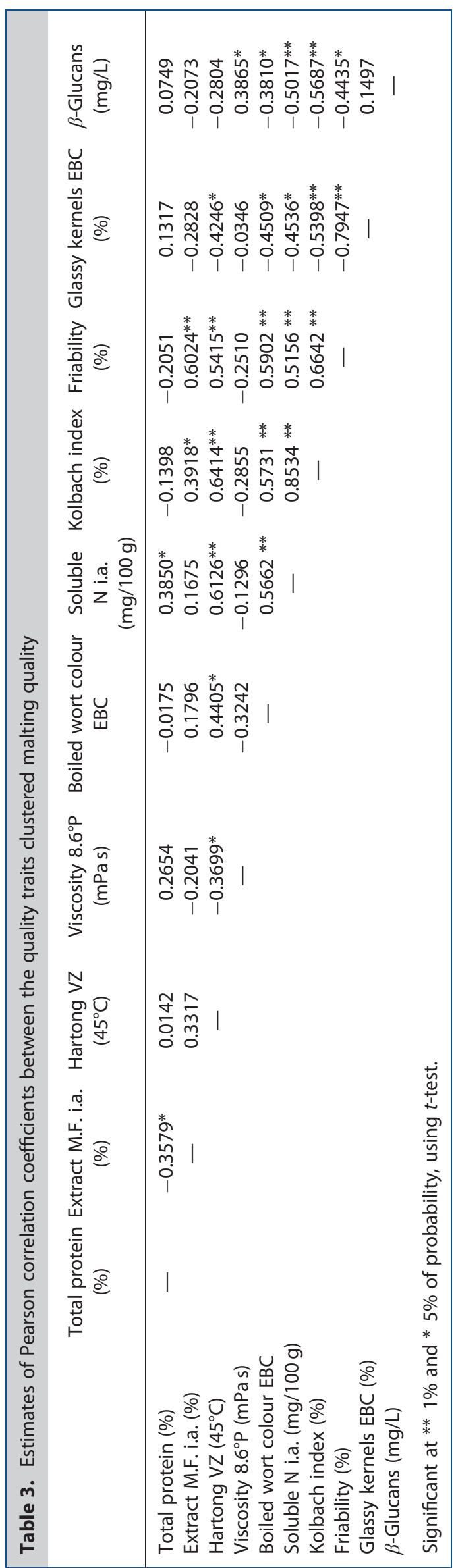


showed a significant and negative correlation in the present research, as was also observed by Fox (45). A positive and significant correlation between the extract and Kolbach index was also observed, similar to the results from Swanston and Ellis (65) and Molina-Cano et al. (14). The $\beta$-glucan was positively and significantly correlated to viscosity, which might be explained by the fact that the $\beta$-glucan is responsible for an increased viscosity (33). Similar results were verified by MolinaCano et al. (14), Bhatty (12) and Wang and Zhang (62).

Another significant correlation, although weak, was verified between protein and $\mathrm{N}$. The total protein content is estimated by multiplying total nitrogen by 6.25 and this might explain part of this low correlation. For decades, researchers have tried to understand the relationship between the protein and extract, with Bishop (66) being one of the pioneers. It is believed that the indirect effects of a protein group or specific protein components have an influence over the extract, including hordein, which is the most important protein fraction of the endosperm $(45,67)$. The correlation between these two factors was negative and significant, corroborating the studies carried out by Ogushi et al. (52), Emebiri et al. (68,69), Qi et al. (41) and Chen et al. (70). This relationship might be explained by the fact that the high protein content decreases the water absorption during germination, also reducing the malt extract levels (68). The dependency between these variables might predict the selection of high extract genotypes, when the protein contents of these genetic materials are low, as mentioned by Fox (55). No other significant correlation was noted among the variable pairs studied (Table 3 ), there not being enough evidence to indicate a subordination relationship among them.

Multivariate analysis of 30 barley accessions based on the malting quality traits allows the characterization and quantification of the genetic variability of these important genetic materials. Based on the method developed by Singh (21), it was possible to classify the relative importance of the 10 evaluated traits regarding the genetic variability, indicating that the soluble nitrogen was the variable that contributed the most (86.6\%), followed by $\beta$-glucan (12.5\%; Table 2 ). The dissimilarity index for each pair of accessions, using the standardized average Euclidian distance, ranged from 1.13 to 1.78 , with an average of 1.36. This amplitude reflects a wide genetic variability among the accessions, a fundamental condition for future studies on genetic selection and improvement. A major genetic similarity was found in PFC 214827-10 and PFC 2004033 (0.42). A highest dissimilarity was found for BRS Elis cultivar and the Mexican genotype CIMMYT 25 (2.58). In relation to the average genetic dissimilarity, the lowest absolute value (1.13) was found for PFC 214827-10 genotype, while the BRS Elis cultivar showed the highest average (1.78).

Cluster analysis through a dendrogram showed a high adjustment with a genetic dissimilarity matrix verified by the high $(r=0.88)$ and significant $(p \leq 0.001)$ cophenetic correlation coefficient, being higher than the value $(0.70)$ proposed by Rohlf (27). Through the cluster analysis, two significant groups of similarity were observed, using as the cut point (a stop in the clustering algorithm) the average genetic distance of 1.36 (Fig. 1). The genotype clustering was performed so that there could be a wide view of the barley quality grown in the savanna. It is known that all genotypes from Mexico, the USA, UK and Brazil, but not the German genotypes, were distributed in these two groups. The barley elite accessions analysed in the present study showed a high genetic variability regarding the traits evaluated and no specific cluster tendency as to the origin of the accessions was found (Fig. 2). This might be explained by the fact that the qualitative traits are complex variables and depend on the interaction of a significant number of gene expressions $(69,71)$, not being related to the geographic origin. The elite accessions might have a genetic blend that occurred during the development of the materials in the genetic improvement programmes performed in each country of origin. Therefore, based on the genetic distance among the accessions of different clusters, the

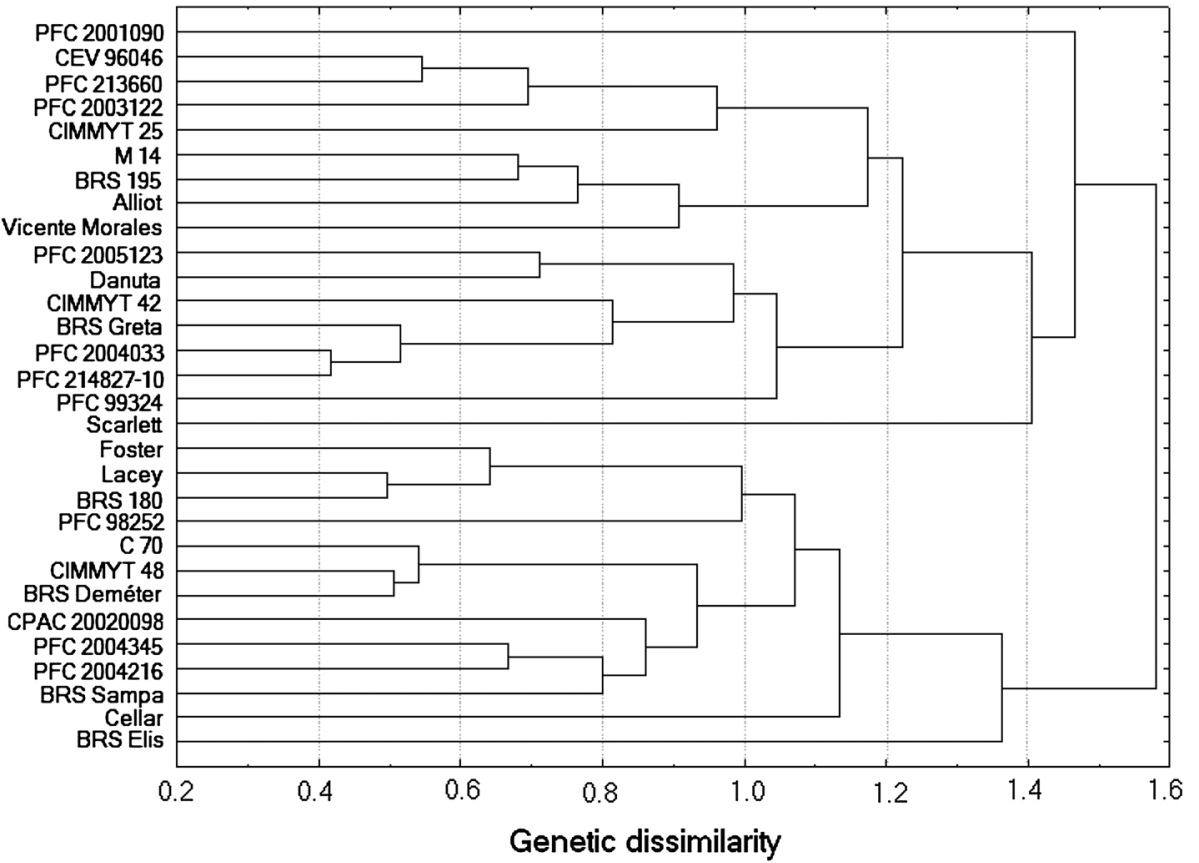

Figure 1. Cluster analysis of 30 barley genotypes based on the genetic dissimilarity matrix calculated through the standardized average Euclidian distance, using 10 traits related to the malting quality. UPGMA method was used as the cluster criteria. The value of the cophenetic correlation coefficient $(r)$ is 0.88 . 


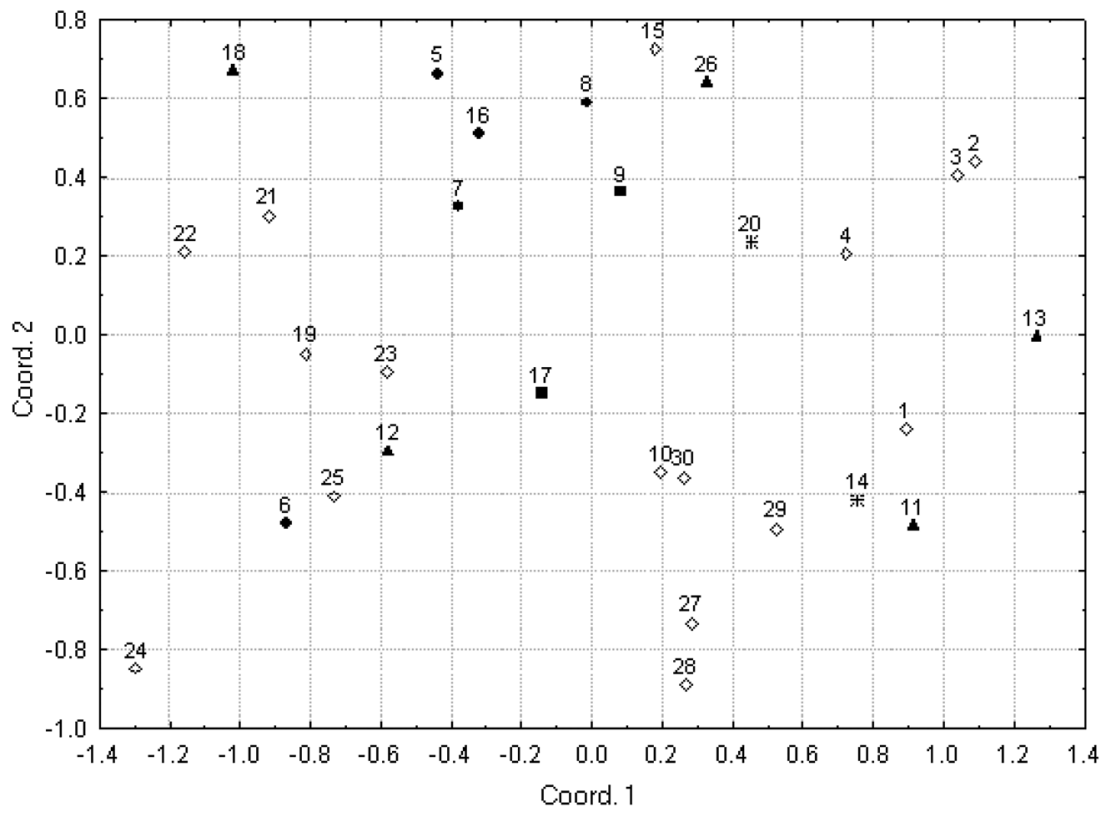

Figure 2. Dispersion of 30 barley accessions based on the standardized average Euclidian distance calculated using 10 traits related to the malting quality. The figures cor-

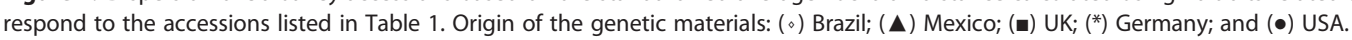

contrasting parents might be selected and used in a hybridization programme for a greater variability concerning the malting quality, as recommended by Sarkar et al. (57).

As stated above, the distribution of the genetic variability regarding the different geographic origins was dispersive. However, a concentration of American genotypes was observed, except for genotype C-70 (Fig. 2). On the other hand, the genotypes collected from other breeding programmes were not concentrated, similar to the observation made by Verma and Sarkar (31).

Based on the characterization and variability traits, a probable crossing would be between the English cultivar Cellar - of proven malting quality - and PFC 2004033 and PFC 214827-10 genotypes selected and adapted to the irrigation conditions of the savanna, because of their elite genetic constitution for grain yield. The same could be done with the malting cultivar BRS Deméter and the American Lacey with the accession PFC 2001090. It is possible that the resulting individuals from these crossings could express a high heterozygosity of the loci involved, providing the possibility of a selection that includes the quality traits and appropriate agronomic variables for the irrigated environment in the savannas.

As for the genetic materials used in genetic improvement programmes in Brazil (Fig. 3), it could be noted that, after redirectioning and remodelling the Brazilian irrigated barley programme in 2000, several barley accessions used in the

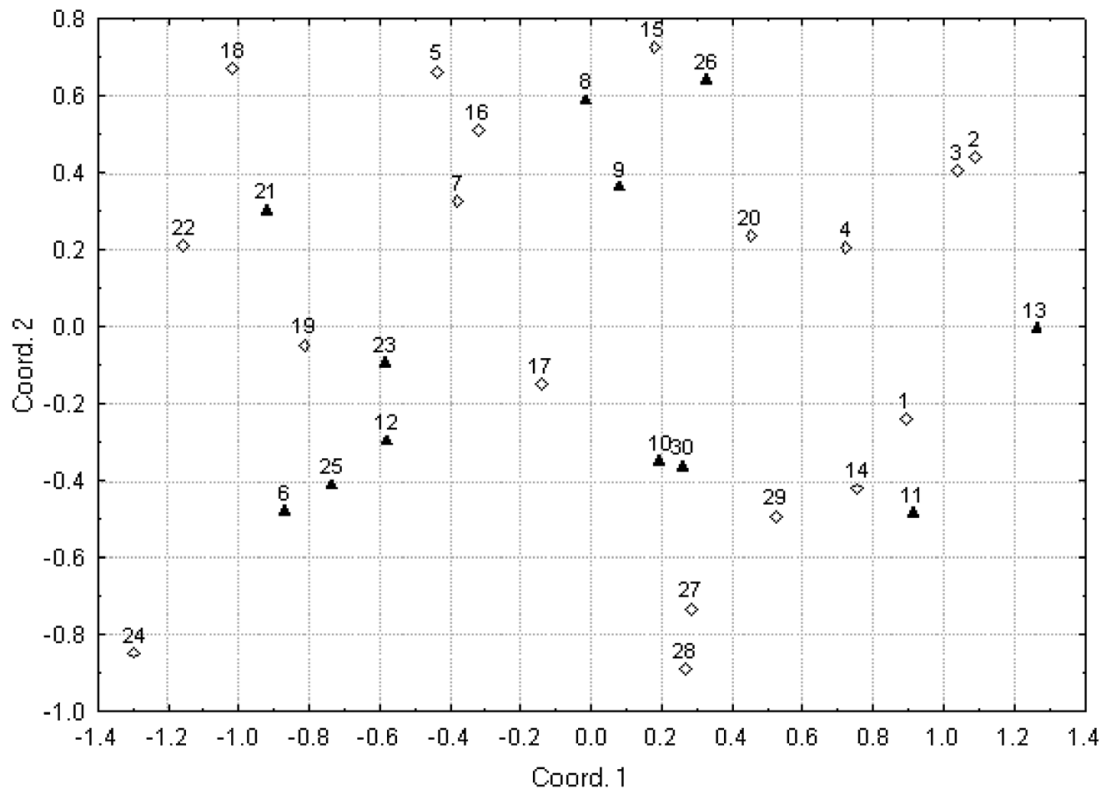

Figure 3. Dispersion of 30 barley accessions based on the standardized average Euclidian distance calculated using 10 traits related to the malting quality. The figures correspond to the accessions illustrated in Table 1. $(\diamond)$ Genetic materials currently used and $(\boldsymbol{\Delta})$ not used in improvement programmes in Brazil. 


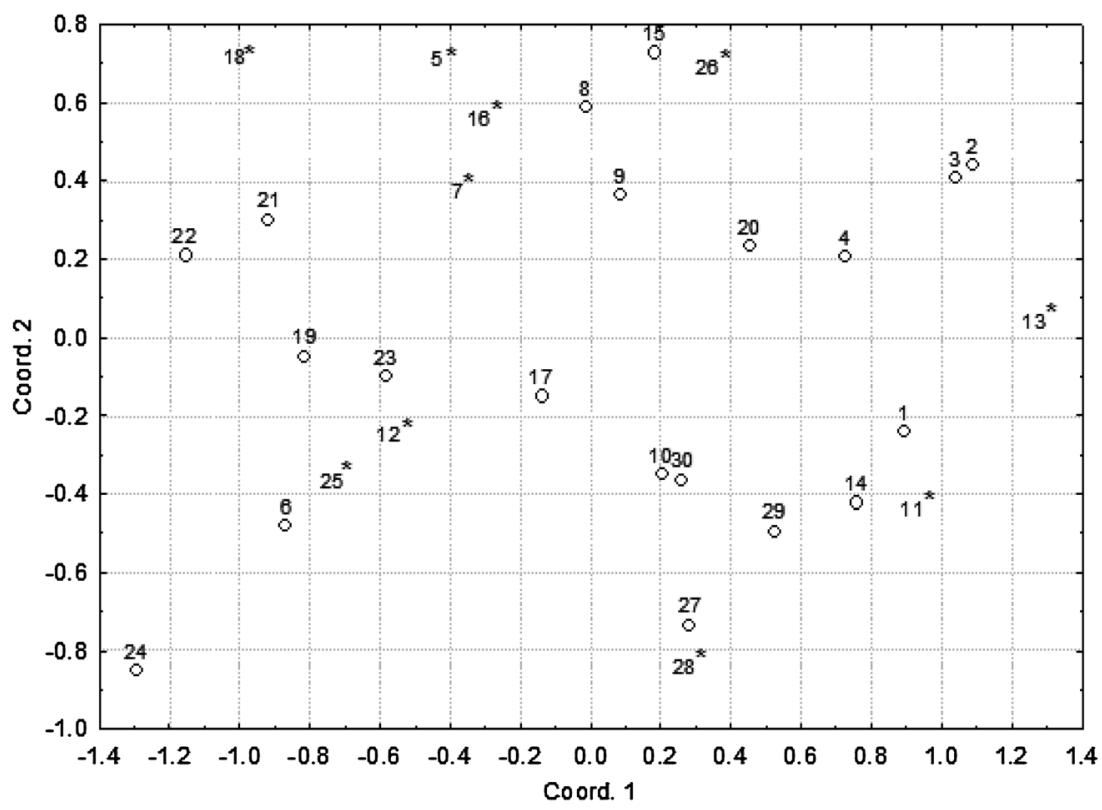

Figure 4. Dispersion of 30 barley accessions based on the standardized average Euclidian distance calculated using 10 traits related to malting quality. ${ }^{*}$ Six-rowed materials; ${ }^{\circ}$ two-rowed materials.

crossings are widely distributed within the group. These results clearly show the existence of a wide genetic variability in the group of genotypes evaluated, being a direct outcome of the analysis of genetic materials from different origins and improvement programmes. This significant variability in Brazilian barley cultivars, even those resulting from a self-pollinated crop, was also detected by Sarkar et al. (57), Psota et al. (49) and Verma and Sarkar (31). In order to meet the demands of the irrigated barley crop in the Brazilian savanna, wider genotype variability with malting traits in the hybridizations were introduced and used. When analysing the dispersion of accessions in relation to the characteristic 'number of rows/ears' (six-/two-rowed) in comparison to the two first principal coordinates (Fig. 4), no cluster tendency in the twoor six-row genetic materials was observed, as shown in the dendrogram based on the UPGMA method.

\section{Conclusions}

The results show that barley in the savanna has sufficient quality to be included in the national malt programme. There is a genetic variability among the barley genotypes evaluated through the malting qualitative traits, which should be exploited in the Brazilian irrigated barley improvement programme. The qualitative traits that contribute the most to the genetic diversity appear to be soluble nitrogen and $\beta$-glucan, and the less variable characteristics are protein content and malt viscosity.

\section{References}

1. Cattivelli, L., Delogu, G., Terzi, V., and Michele, A. (1994) Progress in barley breeding, in Genetic Improvement of Field Crops (Slafer, G. A. Ed.) pp. 95-181, Marcel Dekker: New York.

2. Yalçin, E., Çelik, S., Akar, T., Sayim, I., and Köksel, H. (2007) Effects of genotype and environment on $\beta$-glucan and dietary fiber contents of hull-less barley grown in Turkey, Food Chem. 101, 171-176.

3. Amabile, R. F., Minella, E., Oliveira, M. O., and Fronza, V. (2007) Cevada (Hordeum vulgare L.), in 101 culturas: manual de tecnologias agrícolas (Paula, Júnior, T. J. and Venzon, M. I., Eds) pp. 263-268, EPAMIG: Belo Horizonte, MG.

4. Amabile, R. F. (2007) Cevada: um exemplo de cultura alternativa para o sistema irrigado do Cerrado, in Pesquisa, desenvolvimento e inovação para o Cerrado (Faleiro, G. F. and Sousa, E. S. I., Eds) pp. 69-72, Embrapa Cerrados: Planaltina, DF.

5. Eiten, G. (1993) Vegetação do Cerrado (Pinto, M. N., Ed.) pp. 17-73, Editora Universidade de Brasília, Brasília.

6. Adámoli, J., Macedo, J., Azevedo, L. G., and Netto, J. M. (1987) Caracterização da região dos Cerrados in Solos dos Cerrados: Tecnologias e Estratégias de Manejo (Goedert, W. J., Ed.) pp. 33-98, Nobel, São Paulo.

7. Resende, M., Curi, N., de Rezende, S. B., and Corrêa, G. F. (2002) Pedologia: Base Para Distinção de Ambientes, 4th ed., NEPUT: Viçosa.

8. Valls, J. F. M. (2007) Caracterização de recursos genéticos vegetais, in Recursos Genéticos Vegetais (Nass, L. L. I., Ed.) pp. 281-305, Embrapa Recursos Genéticos e Biotecnologia: Brasília.

9. Cruz, C. D., and Carneiro, P. C. S. (2003) Modelos biométricos aplicados ao melhoramento genético, UFV: Viçosa.

10. Manninen, O. (2000) Genetic mapping of traits important in barley breeding, dissertation, University of Helsinki. Available from http:// ethesis.helsinki.f/julkaisut/mat/bioti/vk/manninen (accessed June 2014).

11. Matus, A., and Hayes, P. M. (2002) Genetic diversity in three groups of barley germplasm assessed by simple sequence repeats, Genome 45, 1095-1106.

12. Bhatty, R. S. (1999) The potential of hull-less barley, Cereal Chem. 76, 589-599.

13. Fox, G. P., Kelly, A. M., Cakir, M., Bloustein, G., Poulsen, D. M. E Inkerman, P. A., and Henry, R. J. (2006) Genetic impacts of the hull on barley grain quality, J. Inst. Brew. 112, 101-107.

14. Molina-Cano, J. L., Francesch, M., Perez-Vendrell, A. M., Ramo, T., Voltas, J., and Brufau, J. (1997) Genetic and environmental variation in malting and feed quality of barley, J. Cereal Sci. 25, 37-47.

15. Wright, L. (2000) Malting barley for new millennium, in Breeding Barley in the New Millennium, Proceedings of International Symposium (Vivar, $\mathrm{H}$. E., and McNab, A., Eds) pp. 28-33, CIMMYT: Mexico.

16. Baik, B. K. and Ullrich, S. E. (2008) Barley for food: Characteristics, improvement, and renewed interest, J. Cereal Sci. 48, 233-242.

17. Empresa Brasileira de Pesquisa Agropecuária, Serviço Nacional de Levantamento e Conservação de Solos. (1997) Manual de Métodos de Análise de Solo, Rio de Janeiro.

18. European Brewery Convention. (1997) Analytica - EBC. Fachverlag Hans Carl: Nurnberg.

19. Yasuhara, T. and Nokihara, K. (2001) High-throughput analysis of total nitrogen content that replaces the classic Kjeldahl method, J. Agric. Food Chem. 49, 4581-4583. 
20. Steel, R. G. D. and Torrie, J. H. (1980) Principles and Procedures of Statistics - A Biometrical Approach, 2nd ed., McGraw-Hill: New York.

21. Singh, D. (1981) The relative importance of characters affecting genetic diversity, Indian J. Genet. Plant. Breed. 41, 237-245.

22. Cruz, C. D. (2007) Programa Genes: aplicativo computacional em genética e estatística. Versão Windows - 2007, (UFV Ed.) 442 p., MG, Viçosa.

23. Carvalho, F. I. F., Lorencetti, C., and Benin, G. (2004) Estimativas e implicações da correlação no melhoramento vegetal, Universitária da UFPel: Pelotas.

24. Sneath, P. H. A. and Sokal, R. R. (1973) Numerical Taxonomy: The Principles and Practice of Numerical Classification, W. H. Freeman: San Francisco, CA.

25. Statsoft Inc. (1999) Statistica for Windows [Computer Program Manual], StatSoft Inc.: Tulsa, OK.

26. Sokal, R. R. and Rohlf, F. J. (1962) The comparison of dendrograms by objective methods, Taxon 11, 30-40.

27. Rohlf, F. J. (2000) NTSYS-pc: Numerical Taxonomy and Multivariate Analysis System, version 2.1, New York.

28. Bichoński, A. and Śmiałowski, T. (2004) Relationships and correlations between brewery traits of the spring barley varieties, Electronic J. Polish Agric. Univ. 7. Available from: http://www.ejpau.media.pl/ volume7/issue2/food/art-06.html (accessed June 2014).

29. Amabile, R. F., Aquino, F. G., Minela, E., Monteiro, V. A., Ferrari, R, Ciulla, C., Ribeiro, Junior, W. Q., and Fernandes, F. D. (2007) Qualidade industrial do malte proveniente de genótipos de cevada cervejeira cultivados sob irrigação no Cerrado, in XXVI Reunião Nacional de Pesquisa de Cevada, Embrapa Trigo Documentos 76, 430-442.

30. Evans, D. E., Dambergs, R., Ratkowsky, D., Li, C., Harasymow, S., Roumeliotis, S., and Eglinton, J. K. (2010) Refining the prediction of potential malt fermentability by including an assessment of limit dextrinase thermostability and additional measures of malt modification, using two different methods for multivariate model development, J. Inst. Brew. 116, 86-96.

31. Verma, R. P. S. and Sarkar, B. (2010) Diversity for malting quality in barley (Hordeum vulgare) varieties released in India, Indian J. Agric. Sci. 80, 493-500.

32. Fox, G. P.,Panozzo, J. F., Li, C. D., Lance, R. C. M., Inkerman, P. A., and Henry, R. J. (2003) Molecular basis of barley quality, Aust. J. Agric. Res. 54, 1081-1101.

33. Mather, D. E., Tinker, N. A., Laberge, D. E., Edney, M., Jones, B. L., Rossnagel, B. G., Legge, W. G., Briggs, K. G., Irvine, R. B., Falk, D. E., and Kasha, K. J. (1997) Regions of the genome that affect grain and malt quality in a North American two-row barley cross, Crop. Sci. 37, 544-554.

34. Passarella, V. S., Savin, R., and Slafer, G. A. (2005) Breeding effects on sensitivity of barley grain weight and quality to events of high temperature during grain filling, Euphytica 141, 41-48.

35. Amabile, R. F., Araújo, D. S., Fernandes, F. D., Inácio, A. A. N., Ribeiro, Junior, W. Q., Guerra, A. F., and Ramos, M. L. G. (2009) Efeito das doses de nitrogênio, via fertirrigação, na produção e qualidade de cevada malteira, in XXVII Reunião Nacional de Pesquisa de Cevada 27, Embrapa Trigo 1, CD ROM.

36. Amabile, R. F., Minella, E., Inácio, Á. Á. N., Araújo, D. S., Monteiro, V. A., and Carvalho, F. H. (2007) Qualidade fisiológica e sanitária da cultivar de cevada (Hordeum vulgare L.) cervejeira BRS 195 produzida em diferentes locais do estado de Goiás, in XXVI Reunião Nacional de Pesquisa de Cevada, Embrapa Trigo Documentos 76, 754-766.

37. Amabile, R. F., Minella, E., Lopes, F. G., Fidelis, L. R. G., Guerra, A. F., Silva, D. B., Ribeiro, Junior, W. Q., and Gomes, A. C. (2005) Análise de linhagens de cevada dística sob irrigação no Cerrado, in XXV Reunião Nacional de Pesquisa de Cevada, Fundação Agrária de Pesquisa Agropecuária, 141-154.

38. Amabile, R. F., Minella, E., Barbosa, F. S., Yamanata, C., Ribeiro, Junior, W. Q., and Pereira, V. C. (2009) Avaliações de valor de cultivo e uso (VCU) de $1^{\circ}$ e $2^{\circ}$ Ano de cevada irrigada no Cerrado em 2007, in XXVII Reunião Nacional de Pesquisa de Cevada 27, Embrapa Trigo 1, CD ROM.

39. Guerra, A. F. (1995) Tensão de áqua no solo: efeito sobre produtividade e qualidade dos grãos de cevada, Pesq. Agropec. Bras. 30, 245-254.

40. Eagles, H. A., Bedggood, A. G. J., Panozzo, J. F., and Martin, P. J. (1995) Cultivar and environmental effects on malting quality in barley, Aust J. Agric. Res. 46, 831-844.
41. Qi, J., Chen, J., Wang, J., Wu, F., Cao, L., and Zhang, G. (2005) Protein and hordein fraction content in barley seeds as affected by sowing date and their relations to malting quality, J. Zhejiang Univ. Sci. B 6, 1069-1075.

42. Brasil. (1996) Ministério da Agricultura, Pecuária e Abastecimento. Portaria n. 691, de 22 de Novembro de 1996. Aprova a norma de identidade e qualidade da cevada, para comercialização interna, Diário Oficial [da] República Federativa do Brasil, Brasília, DF, 25 November, Seção 1, pp. 24751-24752.

43. Brewing and Malting Barley Research Institute (2014) Quality factors in malting barley. Available from: http://www.bmbri.ca (accessed June 2014).

44. Chapman, S. R. and Carter, L. P. (1976) Crop Production: Principles and Practices, pp. 311-324, W. H. Freeman: San Francisco, CA.

45. Fox, G. P. (2008) Biochemical and molecular evaluation of quality for malt and feed barley, Lismore, PhD thesis, Southern Cross University, Australia.

46. Brasil (1977) Ministério da Agricultura, Pecuária e Abastecimento, Portaria n. 166, de 12 de Abril de 1977, Diário Oficial [da] República Federativa do Brasil, Brasília, DF, 18 May, Seção 1.

47. Amabile, R. F., Minella, E., Guerra, A. F., Silva, D. B., Albrecht, J. C., and Antoniazzi, N. (2008) BRS Deméter: nova cultivar de cevada cervejeira irrigada para o Cerrado do Brasil Central, Pesq. Agropec. Bras. 43, 1247-1249.

48. Silva, D. B., Guerra, A. F., Minella, E., and Arias, G. (2000) BRS 180: cevada cervejeira para cultivo irrigado no Cerrado, Pesq. Agropec. Bras. 35, 1689-1694.

49. Psota, V., Hartmann, J., Sejkorová, Š., Loučková, T., and Vejražka, K. (2009) 50 years of progress in quality of malting barley grown in the Czech Republic, J. Inst. Brew. 115, 279-291.

50. Fukuda, K., Saito, W., Arai, S., and Aida, Y. (1999) Production of a novel proanthocyanidin-free barley line with high quality, J. Inst. Brew. 105, 179-183.

51. Ogushi, K., Barr, A. R., Takahashi, S., Asakura, T., Takoi, K., and Ito, K. (2002) Lofty Nijo: A high quality malting barley variety released from an Australian-Japanese collaboration, J. Inst. Brew. 108, 13-18.

52. Ogushi, K., Lim, P., Barr, A. R., Takahashi, S., Asakura, T., and Ito, K. (2002) Japanese barley meets Australia: Quality performance of malting barley grown in different countries, J. Inst. Brew. 108, 303-309.

53. Spiel, G. (1999) Current and future trends in barley quality requirements. Available from: http://www.regional.org.au/au/abts/1999/ spiel.htm (accessed June 2014).

54. Reinold, M. R. (1995) O processo de elaboração do mosto, SP, Aden, São Paulo.

55. Fox, G. P. (2009) Chemical composition in barley grains and malt quality, in Genetics and Improvement of Barley Malt Quality (Zhang, G., and Li, C. I. Eds) pp. 63-98, Springer, London.

56. Kaczmarek, Z., Surma, M., Adamski, T., Jezowski, S., Madajewski, R., Krystkowiak, K., and Kuczyñska, A. (2002) Interaction of gene effects with environments for malting quality of barley doubled haploids, J. Appl. Genet. 43, 33-42.

57. Sarkar, B., Verma, R. P. S., and Mishra, B. (2008) Genetic diversity for malting quality in barley (Hordeum vulgare L.), Indian J. Agric. Sci. $68,163-170$.

58. Brennan, C. S., Harris, N., Smith, D., and Shewry, P. R. (1996) Structural differences in the mature endosperms of good and poor malting barley cultivars, J. Cereal Sci. 24, 171-177.

59. Gallant, D. J., De Monredon, F., Bouchet, B., Tacon, P., and DelortLaval, J. (1991) Cytochemical study of intact and processed barley grain: Options Méditerranéennes - série seminaries, New Trends Barley Qual. Malting Feeding 20, 31-34.

60. Zhang, G., Chen, J., Wang, J., and Ding, S. (2001) Cultivar and environmental effects on $(1 \rightarrow 3,1 \rightarrow 4)$ - $\beta$-D-glucan and protein content in malting barley, J. Cereal Sci. 34, 295-301.

61. MacGregor, A. W. (1996) Malting and brewing science: Challenges and opportunities, J. Inst. Brew. 102, 97-102.

62. Wang, J. M. and Zhang, G. P. (2009) $\beta$-Glucans and Arabinoxylans, Genetics and Improvement of Barley Malt Quality (Zhang, G., and Li, C. Eds) pp. 113-142, Springer: London.

63. Swanston, J. S. (1997) Waxy starch barley genotypes with reduced, $\beta$-glucan contents, Cereal Chem. 74, 452-455.

64. Savin, R. Stone, P. J. Nicolas, M. E, and Wardlaw, I. F. (1997) Grain growth and malting quality of barley 2: Effects of temperature regime before heat stress, Aust. J. Agric. Res. 48, 625-634. 
65. Swanston, J. S., and Ellis, R. P. (1995) Differences in malting performance between barleys grown in Spain and Scotland, J. Inst. Brew. 101, 261-265.

66. Bishop, L. R. (1930) The Institute of Brewing Research Scheme: I. The prediction of extract, J. Inst. Brew. 36, 421-434.

67. Bulman, P., Zarkadas, C. G., and Smith, D. L. (1994) Nitrogen fertilizer affects amino acid composition and quality of spring barley grain, Crop. Sci. 34, 1341-1346.

68. Emebiri, L. C., Moody, D. B., Horsley, R., Panozzo, J. F., and Read, B. J. (2005) The genetic control of grain protein content variation in a double haploid population derived from a cross between Australian and North American two-rowed barley lines, J. Cereal Sci. 41, 107-114.
69. Emebiri, L. C., Moody, D. B., Panozzo, J. F., and Read, B. J. (2004) Mapping of QTL for malting quality attributes in barley based on a cross of parents with low grain protein concentration, Field Crop Res 87, 195-205.

70. Chen, J., Dai, F., Wei, K., and Zhang, G. (2006) Relationship between malt qualities and $\beta$-amylase activity and protein content as affected by timing of nitrogen fertilizer application, J. Zhejiang Univ. Sci. B 7, 79-84.

71. Ceccarelli, S., Grando, S., Capettini, F., and Baum, M. (2007) Barley breeding for sustainable production, in Breeding Major Food Staples (Kang, M. and Priyadarshan, P. M., Eds) pp. 193-216, Blackwell: Ames, IA. 